Situs Jurnal : $\underline{\text { http://ejournal.stiepancasetia.ac.id/index.php/jieb }}$

Jilid 7 Nomor 1 Maret 2021

Hal 102-115

\title{
ANALISIS SISTEM INFORMASI AKUNTANSI PERSEDIAAN BARANG DAGANG PADA CV. A. M. BANJARMASIN
}

\section{Laila Majidah, Imawati Yousida, M. Zaid Abdurakhman}

\begin{abstract}
Abstrak: Penelitian ini bertujuan untuk menganalisis sistem informasi akuntansi persediaan barang dagang pada CV. A.M Banjarmasin. Metode yang digunakan dalam penelitian ini adalah penelitian deskriptif, yang berfokus pada sistem informasi akuntansi persediaan barang dagang pada CV. A.M di Banjarmasin yang seharusnya. Analisis data yang digunakan adalah membandingkan dengan teori sehingga akan diperoleh suatu gambaran terkait system informasi akuntansi dan unsur pengendalian intern terhadap persediaan barang dagang yang diterapkan selama ini. Hasil penelitian menunjukan bahwa terdapat sistem aplikasi khusus yang tidak dipergunakan secara efektif, sehingga sistem aplikasi tersebut tidak bisa dipergunakan untuk pelaporan persediaan barang dagang yang diharapkan dapat membantu tim gudang agar prosedur operasional persediaan barang dagang dapat dikelola dengan baik. Serta sistem pengendalian intern yang masih ada beberapa kelemahan pada saat pelaksanaan tugas pokok dan fungsi antar bagian banyak proses pekerjaan yang tidak ada dokumen rekamannya dan masih belum dapat memisahkan tanggung jawab fungsional secara tegas sehingga terjadi perangkapan tugas. Hal yang demikian akan memudahkan kemungkinan terjadinya penyimpangan atau kecurangan terutama kesalahan pencatatan persediaan barang dagang di gudang.
\end{abstract}

Kata Kunci : Sistem Informasi Akuntansi, Persediaan Barang Dagang, Sistem Pengendalian Intern. 


\section{Latar Belakang Masalah}

Seiring berkembangnya kemajuan tekhnologi informasi dan komunikasi, persaingan bisnis dalam dunia industri semakin ketat. Jumlah perusahaan semakin banyak dan terus melakukan usaha dan strategi dalam mempertahankan bisnisnya. Kesuksesan perusahaan dalam mempertahankan bisnisnya tidak terlepas dari peran perusahaan tersebut dalam mengelola persediaan barang sehingga dapat memenuhi permintaan dari pelanggan semaksimal mungkin. Perusahaan yang mampu mengendalikan dan mengelola persediaannya dengan baik akan dapat memenuhi kebutuhan pelanggan dan tentu saja dapat menjaga kelangsungan bisnisnya dalam dunia industri saat ini. Persediaan barang didalam suatu usaha menjadi hal yang penting bagi suatu perusahaan, karena dari persediaan tersebut bisa mengelola stok barang di gudang yang nantinya akan di jual ke konsumen. Oleh karena itu pengusaha atau pedagang tersebut harus dapat mengelola persediaan barang dengan efektif dan efisien agar sesuai dengan tujuan perusahaan.

Masalah persediaan merupakan permasalahan yang selalu dihadapi para pengambil keputusan dalam bidang persediaan. Persediaan dibutuhkan karena pada dasarnya pola permintaan tidak beraturan. Persediaan dilakukan untuk menjamin adanya kepastian bahwa pada saat dibutuhkan barang-barang tersebut tersedia. Pengolahan data dan informasi secara cepat, tepat dan efisien adalah hal penting yang dibutuhkan bagi setiap perusahaan atau suatu instansi untuk meningkatkan produktifitas pekerjaan, waktu, dan biaya. Agar informasi tersebut dapat menjadi akurat dan relevan maka diperlukan sebuah sistem yang dapat mengatur tentang informasi tersebut. Sistem tersebut biasanya dikenal dengan nama sistem informasi. Salah satu bentuk dari sistem informasi yang berguna bagi perusahaan adalah sistem informasi akuntansi yang secara umum membahas mengenai sistem akuntansi yang berjalan didalam suatu perusahaan. Khususnya pada perusahaan dagang yang kegiatan utamanya adalah menjual barang dagang kepada konsumen secara langsung, maka diperlukan suatu sistem yaitu sistem informasi akuntansi persediaan. Sistem informasi akuntansi persediaan tersebut sagatlah penting bagi perusahaan karena sistem tersebut dapat menjadi patokan apakah perusahaan tersebut berjalan dengan baik atau tidak. Sistem tersebut mencakup keseluruhan mengenai kegiatan operasional yang ada didalam perusahaan. Bagian yang paling penting dari sistem tersebut adalah sistem informasi akuntansi persediaan barang dagang dikarenakan persediaan menjadi salah satu aset yang sangat besar serta terpenting didalam perusahaan saat menjalankan kegiatannya.

CV. A.M merupakan sebuah perusahaan dagang yang bergerak dibidang distributor minuman dalam kemasan yang merupakan distributor yang menjual dengan harga murah sehingga banyak pelanggan ataupun agen yang membeli produk di CV. A.M, baik untuk dijual kembali ataupun dikonsumsi sendiri. Untuk pengambilan produk, perusahaan ini memasoknya dari pabrik yang ada di Jakarta ataupun Surabaya .

Permasalahan yang terjadi di CV. A.M adalah barang tertukar serta stok persediaan barang berkurang. Fenomena yang terjadi terkait dengan sistem informasi akuntansi persediaan adalah pada prosedur penerimaan barang maupun pengeluaran barang yang selama ini untuk pencatatan dan persediaan barang masih dilakukan secara manual oleh admin gudang dan checker gudang hanya melakukan pengecekan barang tanpa pemeriksaan ulang. Segala perhitungan dan pencatatan hanya dicatat dibuku dan laporan stok hanya dicatat di selembar kertas yang mana laporan yang sudah ditulis admin gudang tersebut diserahkan kebagian kantor dan disalin kembali ke komputer untuk pencocokan stok antara pencatatan stok 
fisik gudang dengan stok data komputer. Dari permasalahan yang ada mengakibatkan sulitnya dalam pencarian data barang yang diperlukan karena penumpukan berkas yang banyak. Mengenai aplikasi yang ada dan telah diterapkan hanya digunakan untuk print out invoice dikarenakan untuk pelaporan yang lainnya aplikasi tersebut tidak support, padahal apabila aplikasi tersebut dapat dikelola dengan baik akan menunjang kinerja bagian administrasi untuk melakukan pelaporan karena laporan yang dapat dihasilkan dari aplikasi tersebut adalah laporan atas penjualan, penerimaan, stok persediaan, laporan keuangan, dll.

Berikut adalah jumlah selisih stok barang persediaan yang terjadi selama 3 bulan terakhir :

Tabel 1.1

CV. A.M

Jumlah Selisih Stok Persediaan

Periode Februari s/d April 2020

\begin{tabular}{|c|l|c|}
\hline No. & \multicolumn{1}{|c|}{ Periode } & Jumlah Selisih \\
\hline 1 & Februari 2020 & 8 karton \\
\hline 2 & Maret 2020 & 18 karton \\
\hline 3 & April 2020 & 6 karton \\
\hline
\end{tabular}

Berdasarkan dari uraian latar belakang tersebut, maka akan dilakukan penelitian tentang "Sistem Informasi Akuntansi Persediaan Barang Dagang Pada CV. A.M di Banjarmasin”.

\section{Rumusan Masalah}

1. Bagaimana sistem informasi akuntansi persediaan barang dagang yang dijalankan pada CV. A.M di Banjarmasin selama ini ?

2. Bagaimana sistem informasi akuntansi persediaan barang dagang yang seharusnya untuk CV.A.M di Banjarmasin?

\section{Tujuan Penelitian}

1. Untuk mengetahui bagaimana sistem informasi akuntansi persediaan barang dagang yang selama ini dijalankan pada CV. A.M di Banjarmasin.

2. Untuk memberikan saran bagaimana sistem informasi akuntansi persediaan barang dagang yang seharusnya untuk CV. A.M di Banjarmasin.

\section{Kajian Pustaka}

1. Sistem Informasi Akuntansi

Sistem informasi akuntansi menurut Krismiaji (2015: 4) menyatakan bahwa sebuah sistem yang memproses sebuah data transaksi guna menghasilkan informasi yang bermanfaat untuk mengendalikan dan mengoperasikan bisnis. Sedangkan, menurut Mulyadi (2016: 12), sistem informasi akuntansi merupakan dasar untuk mendapatkan informasi-informasi yang tepat dan cepat.

2. Sistem Informasi Akuntansi Persediaan

Menurut Krismiaji (2015: 395), sistem persediaan adalah sebuah sistem yang memelihara catatan persediaan, memberitahukan manager apabila barang tertentu memerlukan penambahan. Sebuah sistem persediaan memproses dua buah jenis transaksi. Transaksi itu adalah transaksi pembelian dan transaksi penjualan barang dagang.

3. Definisi Persediaan

Persediaan secara umum adalah asset lancer yang terbesar dari perusahaan. Perusahaan dagang selalu membeli barang dagangannya dalam bentuk barang yang siap untuk dijual kembali. Anastasia Diana dan Lilis Setiawati ( 2017:179)

4. Pernyataan Standart Akuntansi Keuangan Persediaan (PSAK) No. 14 Tahun 2018

PSAK 14 persediaan mengatur suatu perlakuan akuntansi untuk persediaan. Namun PSAK 14 tidak berlaku pada hal-hal berikut (paragraph 2) : 
a. Pekerjaan dalam proses yang timbul dalam kontrak kontstruksi, maka termasuk dalam kontrak jasa yang terkait langsung dalam PSAK 34.

b. Instrumen keuangan yang terdapat pada PSAK 50.

c. Aset biologis yang terkait dengan aktivitas agrikultur dan produk aglikultur pada titik panen terdapat pada PSAK 69.

5. Komponen Pengendalian Intern Persediaan

Menurut AICPA (American Institute of Certified Public Accountants) dalam SAS (Statement on Auditing Standarts) No. 78 yang terdapat dalam Standar Profesi Akuntan Publik menyatakan bahwa komponen pengendalian internal terdiri dari :
a. Lingkungan Pengendalian
b. Penilaian Resiko
c. Aktivitas Pengendalian
d. Informasi dan Komunikasi Akuntansi
e. Pemantauan

6. Pengertian dan Unsur-unsur Sistem Pengendalian Intern Persediaan

Pengendalian intern harus dilaksanakan seefektif mungkin dalam suatu perusahaan yang mencegah dan menghindari terjadinya kesalahan, kecurangan, dan penyelewengan. Menurut Sujarweni (2015: 69), sistem pengendalian intern adalah suatu sistem yang dibuat untuk memberi jaminan keamanan bagi unsur-unsur yang ada dalam perusahaan. Dalam setiap pengendalian internal juga terdapat unsur-unsur pokok. Unsurunsur pokok tersebut yaitu :
a. Struktur organisasi yang memisahkan tanggung jawab fungsional secara tegas.
b. Sistem wewenang dan prosedur pencatatan yang memberikan perlindungan yang cukup terhadap

kekayaan, utang, pendapatan, dan biaya.

c. Praktik yang sehat dalam melaksanakan tugas dan fungsi setiap unit organisasi.

\section{Metode Penelitian}

Jenis penelitian yang diteliti adalah penelitian deskriptif kualitatif. Pada penelitian ini peneliti menemukan suatu permasalahan atas persediaan barang pada CV. A.M. Penelitian ini tujuannya untuk menganalisis data dengan cara mendeskripsikan atau menggambarkan data yang telah terkumpul sebagaimana adanya tanpa bermaksud membuat kesimpulan yang berlaku untuk umum atau generalisasi.

\section{Hasil Penelitian}

\section{Data Persediaan Selama 3 Bulan dan Data Stok Selisih}

\section{Tabel 1.3}

CV. A.M

Data Stok Persediaan

Periode Februari s/d April 2020

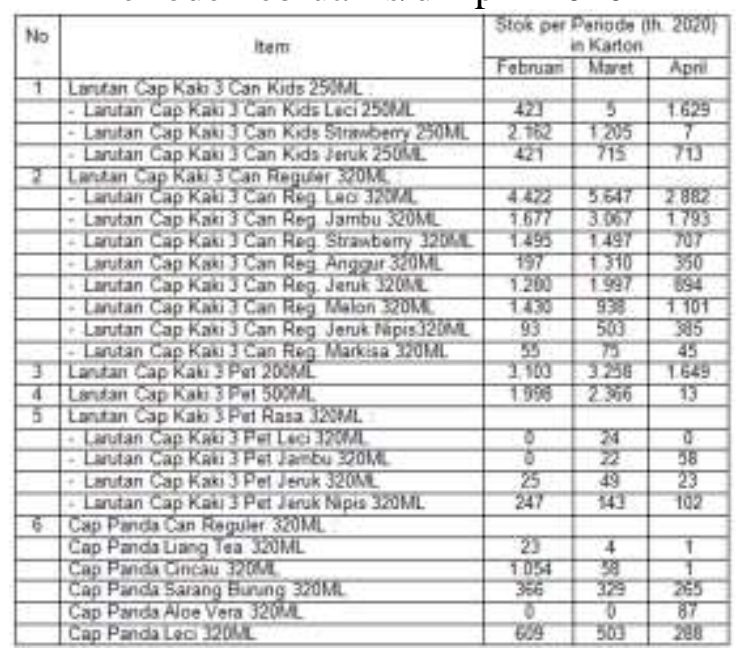


Tabel 1.4

CV. Air Mandiri

Data Stok Selisih

Periode Februari s/d April 2020

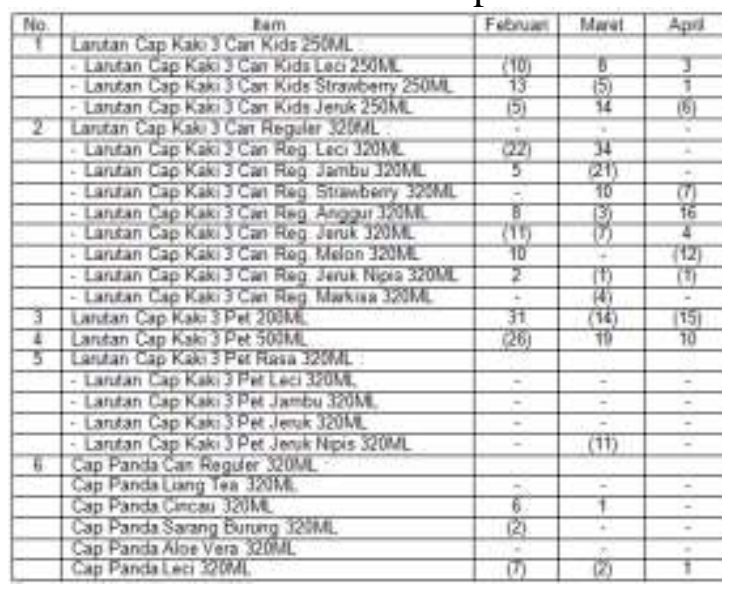

\section{Aplikasi Yang Digunakan}

Aplikasi yang digunakan adalah aplikasi atau sistem untuk distributor ataupun perusahaan dagang, karena pada aplikasi tersebut bisa dipergunakan untuk penginputan ataupun pelaporan seperti pada umumnya, yaitu laporan stok, laporan kas, laporan piutang, dan cetak invoice yang langsung memotong stok yang tercatat di aplikasi atau sistem tersebut.

\section{Pembahasan}

\section{Sistem Informasi Akuntansi}

Persediaan Barang Dagang Pada

\section{A.M Banjarmasin}

a. Komponen Sistem Informasi akuntansi Persediaan Barang Dagang selama ini adalah sebagai berikut :

1) Hardware

Hardware yang digunakan di CV. A.M selama ini hanya satu unit PC dan komputer yang digunakan sebagai pembanding atau pengecekan stok dari bagian gudang. Komputer tersebut juga digunakan untuk keperluan yang lain sehingga menyebabkan bagian dari hardware tersebut belum terintegrasi dengan baik.

2) Software

Software yag digunakan belum berfungsi dengan baik, hal ini dikarenakan pemilihan software yang tidak efektif dan maintenance yang tidak dilakukan secara berkala akibatnya sering terdapat selisih penginputan ataupun sistem tidak berjalan sesuai dengan keperluan ataupun kebutuhan distributor.

Operating Sistem (OS) saat ini menggunakan OS Microsoft Window 7 dengan program aplikasi adalah sebagai berikut :

a) Program Integrted System untuk Distributor Edition 2018 V $1.24 \mathrm{Ok}$

b) Microsoft Office Excel 2010

\section{3) Brainware}

Brainware di CV. A.M saat ini yang mempunyai jabatan sebagai admin gudang dan telah bekerja selama 2 tahun. Akan tetapi, selain menginput data admin tersebut juga biasa membantu mempersiapkan atau mengawasi barang di gudang pada saat barang akan dibawa pelanggan ataupun oleh tim pengantaran.

4) Prosedur

Dalam melihat sistem informasi yang diterapkan pada CV. A.M yang langsung berkaitan dengan bagian gudang dalam mengelola persediaan barang dagang masuk dan barang dagang keluar. Prosedur yang dimaksud adalah sebagai berikut :

a) Prosedur Pembelian Barang Sistem pembelian pada CV. A.M tidaklah sama dengan sistem pembelian 
pada umumnya. Sistem yang ada di perusahaan tersebut yaitu secara otomatis barang pesanan diperhitungkan oleh pihak supplier sesuai dengan kebutuhan barang mana yang lebih cepat terjual dengan melihat pelaporan secara online oleh bagian admin penjualan.

Setelah proses perhitungan barang selesai, pihak supplier akan meminta persetujuan kepada pihak CV. A.M agar barang dapat di proses dan dilakukan pengiriman ke gudang. Kemudian apabila telah mendapat persetujuan, barang langsung di kirim.

b) Prosedur Penerimaan Barang

Setiap barang yang datang atau yang masuk dari supplier, sebelumnya sudah diinformasikan dari pihak ekspedisi kepada bagian kantor, kemudian apabila sudah tiba di gudang langsung di cek oleh Checker gudang yang mana supplier memberikan surat jalan kepada bagian gudang untuk mengetahui jumlah dan barang apa saja yang di terima.

Setelah melakukan proses bongkar barang dan pengecekan oleh checker gudang baru ke bagian admin gudang untuk dilakukan pencatatan sebagai barang masuk.

c) Prosedur Pengeluaran Barang Pada proses barang keluar, pelanggan yang ingin memesan barang bisa datang langsung ke kantor atau pemesanan yang dilakukan dapat melalui sales. Pelanggan yang telah selesai melakukan transaksi pembelian barang di bagian kantor, kemudian pelanggan datang ke bagian gudang untuk mengambil barang dan memberikan daftar permintaan barang yang sudah dilampirkan oleh bagian kantor sesuai dengan pesanan dari pelanggan ke bagian admin gudang untuk melakukan proses pengeluaran barang kepada pelanggan. Setelah itu admin gudang akan melakukan pencatatan sebagai barang keluar.

5) Data

Dari data yang di proses sering terjadi ketidakcocokan antara perhitungan fisik dengan perhitungan yang ada pada dokumen, sehingga sering mengakibatkan selisih. Berikut adalah dokumen-dokumen yang berhubungan dengan pembelian, penyimpanan, ataupun pengeluaran barang digudang oleh perusahaan tersebut :
a) Surat Jalan Pembelian
b) Invoice Pembelian
c) Faktur Penjualan
d) Form Permintaan Barang Gudang

b. Unsur Pengendalian Intern yang selama ini dilakukan di CV. A.M Banjarmasin adalah sebagai berikut :

1) Struktur organisasi yang memisahkan tanggung jawab fungsional secara tegas.

Masih ada beberapa karyawan yang pengerjaanya rangkap jabatan dan kurangnya ketelitian pada pengawasan barang dagang. Dalam hal ini rangkap jabatan yang dimaksud contohnya adalah seperti bagian admin gudang. Admin gudang seharusnya hanya berfokus pada segala pencatatan yang berhubungan dengan gudang. 
Terkadang admin gudang juga turun langsung dalam hal mengawasi bongkar muat barang, sehingga mengakibatkan admin tersebut kurang fokus pada fungsi operasinya.

Sedangkan kurangnya ketelitian pada pengawasan barang dagang yang dimaksud adalah pada checker gudang. Checker gudang sangat berperan penting untuk mengawasi keluar masuknya barang dagang di gudang agar perhitungan fisik barang dagang tidak selisih terlebih adalah tukar variant yang sering mengakibatkan selisih dengan pencatatan admin gudang. Akan tetapi, suatu hal yang sering terjadi adalah checker gudang tidak melakukan pengecekan rasa atau variant barang dagang yang masuk ke gudang sehingga hal itu juga berpengaruh terhadap selisihnya barang dagang di gudang.

2) Sistem wewenang dan prosedur pencatatan persediaan yang memberikan perlindungan yang cukup terhadap kekayaan, utang, pendapatan, dan biaya.

Pada CV. A.M Banjarmasin telah dilakukan otorisasi terhadap dokumen yang digunakan dalam posedur pembelian dan penjualan barang dagang oleh bagian yang berwenang. Dokumen dari prosedur pembelian yaitu tidak ada nota pembelian melainkan Surat Jalan langsung yang diterima pada saat penerimaan barang. Barang selesai diterima, surat jalan tersebut ditanda tangani dan di stemple oleh checker gudang sebagai bagian yang berwenang, selanjutnya oleh bagian keuangan surat jalan di arsip dengan invoice yang diterbitkan dari supplier. Pada saat dilakukannya pembayaran dari invoice tersebut, bagian keuangan akan memberitahukan lewat email ke supplier berupa bukti pembayaran dan rekapitulasi daftar invoice yang dibayar lalu surat jalan dan invoice yang di arsip di cap stemple lunas.

Dokumen dari prosedur penjualan yaitu nota penjualan yang diterima pembeli beserta form permintaan barang yang digunakan untuk bagian gudang mengeluarkan barang pesanan. Nota penjualan dibuat oleh fungsi penjualan yang kemudian diotorisasi dengan membubuhkan tanda tangan pembeli sebagai bukti telah terjadinya transaksi penjualan. Nota penjualan yang diserahkan kepada fungsi kas diotorisasi dengan membubuhkan cap stemple lunas sebagai bukti bahwa uang sudah diterima dan barang yang dijual sudah diserahkan kepada pembeli.

Adapun bagan alir (flowchart) sistem sistem pengendalian intern atas persediaan barang dagang $\mathrm{CV}$. A.M Banjarmasin yang berjalan, yaitu prosedur pembelian barang dagang, prosedur penerimaan atau penyimpanan barang gudang dan oleh perusahaan tersebut :
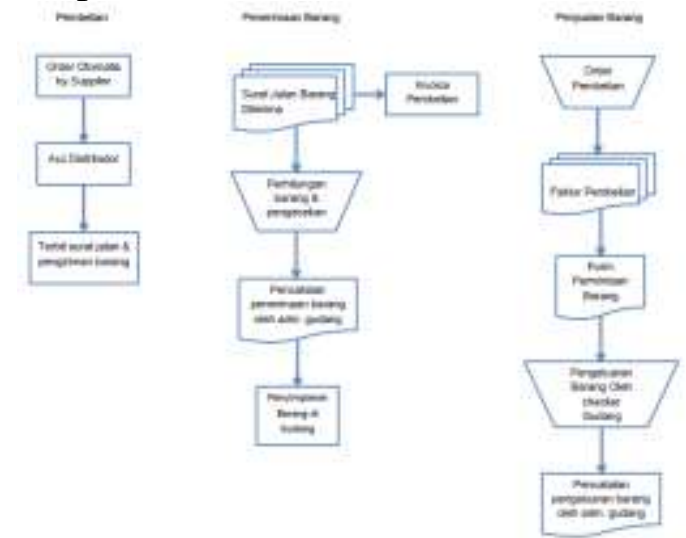

Gambar : 4.3 Flowchart Prosedur Persediaan Barang Dagang Selama Ini

3) Praktik yang sehat dalam melaksanakan tugas dan fungsi setiap unit organisasi yang belum dijalankan dengan efektif, hal yang dimaksud ialah sebagai berikut :

a) Penggunaan formulir bernomor urut tercetak yang 
penggunaannya harus

dipertanggungjawabkan oleh yang berwenang.

CV. A.M Banjarmasin tidak menggunakan formulir bernomor urut cetak melainkan hanya catatan manual dengan nama barang disetiap bagian depan buku stok.

b) Pemeriksaan mendadak (surprised audit) dilaksanakan tanpa pemberitahuan terleih dahulu kepada pihak yang akan diperiksa dengan jadwal yang teratur.

Pada CV. A.M Banjarmasin selama ini tidak pernah melakukan pemeriksaan secara mendadak kepada pihak-pihak yang ada di perusahaan terutama pada bagian gudang yang dikarenakan tidak ada pihak yang melaksanakan.

c) Setiap transaksi tidak boleh dilaksanakan dari awal sampai akhir oleh satu orang atau unit organisasi, tanpa campur tangan dari orang atau unit organisasi lain.

Pada CV. A.M Banjarmasin pada dasarnya setiap melakukan semua transaksi melibatkan beberapa bagian yang ada dalam perusahaan. tetapi ada saat-saat tertentu suatu transaksi dilakukan oleh satu bagian saja yaitu pada transaksi retur barang dari sales penjualan kanvas, admin gudang yang pada dasarnya berwenang sebagai fungsi gudang yang mencatat setiap transaksi digudang sedang off dan tidak ada yang menggantikan sementara, maka checker gudang yang berfungsi sebagai pengecekan barang juga menangani pencatatan manual yang sering dilakukan oleh admin gudang. Adanya hal demikian membuat internal check terhadap pelaksanaan tugas setiap unit organisasi yang terkait tidak terjadi pada saat transaksi tersebut, sehingga pelaksanaan tugas memungkinkan terjadinya praktik kerja yang tidak sehat.

d) Perputaran jabatan (job rotation).

Pada CV. A.M perputaran jabatan hanya dilaksanakan oleh tim sales, untuk setiap karyawan yang lain hanya menduduki posisi yang sama dari tahun ke tahun. Hal ini dilakukan karena spesifikasi keahlian yang berbeda dari masing-masing karyawan.

e) Keharusan pengambilan cuti bagi karyawan yang berhak.

Tidak ada keharusan pengambilan cuti pada CV. A.M Banjarmasin. Jika karyawan yang berhalangan hadir harus meminta ijin terlebih dahulu kepada supervisor operasional.

f) Diadakan pencocokan fisik kekayaan dengan catatannya secara periodik.

Selama ini perusahaan telah melakukan pencocokan fisik kekayaan berupa barang dagang dengan catatan manual berupa laporan stok barang. Tetapi kegiatan tersebut hanya dilakukan pada saat pimpinan meminta informasi data persediaan barang dagang dan kegiatan tersebut tidak dilakukan secara periodik. Hal tersebut mengakibatkan saat terjadinya transaksi, informasi data stok persediaan barang dagang yang disajikan tidak valid.

g) Pembukuan unit organisasi yang bertugas untuk mengecek 
efektivitas unsur-unsur sistem pengendalian intern yang lain.

Pada CV. A.M Banjarmasin tidak memiliki pengawasan internal.

h) Tidak semua karyawan yang mutunya sesuai dengan tanggung jawabnya.

$$
\text { Pada saat rekrut }
$$

karyawan, $\quad$ CV. A.M

Banjarmasin mengadakan seleksi penerimaan tidak semua calon karyawan memiliki ahli dan pengalaman sesuai dengan posisi yang dibutuhkan.

\section{Sistem Informasi Akuntansi}

Persediaan Barang Dagang yang

Seharusnya pada CV. A.M di

\section{Banjarmasin.}

a. Komponen Sistem Informasi Akuntansi Persediaan Barang Dagang yang seharusnya adalah sebagai berikut :

\section{1) Hardware}

Hardware yang digunakan untuk sistem informasi akuntansi harus sesuai dengan kebutuhan sistem informasi akuntansi persediaan barang dagang pada perusahaan yang terus meningkat dari sisi penjualan dan dapat diterapkan sesuai dengan kemampuan keuangan perusahaan. Spesifikasi hardware yang dipilih harus sesuai degan kemampuan keuangan, situasi, kondisi, dan kebutuhan manajemen perusahaan, serta sumber daya manusia yang tersedia di perusahaan tersebut. Sehingga nantinya penggunaan komputer dalam sistem informasi akuntansi persediaan barang dagang dapat benar-benar efektif dalam mengahsilkan informasi persediaan barang dagang pada perusahaan.

2) Software
Dalam memilih software apa yang akan dipakai akan lebih baik memilih dulu sistem operasi apa yang akan digunakan sesuai dengan aplikasi yang akan dioperasikan. Lebih baik memilih software lama yang telah teruji daripada software baru yang kelihatan bagus. Karena hampir semua aplikasi sistem informasi akuntansi saat ini berbasis jaringan maka sudah tentu kita memilih aplikasi yang dapat dijalankan pada jaringan tersebut.

Sistem operasi yang dipakai harus disesuaikan dengan komputer yang akan menjalankannya. Penggunaan software terbaru namun tidak didukung oleh hardware yang baru juga akan menyebabkan eror atau tidak berjalannya aplikas dengan baik. Maka darii itu harus ada kecocokan antara sistem operasi dengan hardware yang digunakan.

3) Brainware

Brainware harus mampu membangun dan menjalankan sistem informasi akuntansi dan tidak sembarang orang, akan tetapi orang yang memiliki kompetensi atau orang yang memiliki keahlian sesuai dengan jenjangnya.

4) Prosedur

Agar sistem informasi akuntansi dapat berjalan dengan baik, antara satu prosedur dengan prosedur yang lainnya harus terjalin kerjasama yang baik. Jangan sampai satu prosedur berjalan sendiri dan tidak terkait dengan prosedur yang lain.

5) Data

Dari data-data yang di proses, harus menghasilkan data serta informasi yang akurat dan dapat dipertanggung jawabkan, karena 
kualitas informasi yang dihasilkan sangat tergantung kepada kualitas data yang disajikan.

b. Unsur Sistem Pengendalian Intern Persediaan Barang Dagang yang seharusnya dilakukan di CV. A.M ialah sebagai berikut :

1) Struktur organisasi yang memisahkan tanggung jawab fungsional secara tegas.

Pada CV. Air Mandiri Banjarmasin seharusnya dilakukan pemisahan fungsi dalam pelaksanaan prosedur persediaan barang dagang. Rangkap jabatan sangat tidak disarankan terkecuali jabatan yang digantikan secara sementara. Apabila suatu perusahaan yang melaksanakan kegiatannya sehingga masing masing bagian dapat mempertanggungjawabankan sesuai uraian tugas masing masing.

2) Sistem wewenang dan prosedur pencatatan persediaan yang memberikan perlindungan yang cukup terhadap kekayaan, utang, pendapatan, dan biaya.

Prosedur pencatatan yang baik akan menjamin data yang direkam dalam catatan akuntansi dengan tingkat keakuratan yang tinggi. Setiap terjadi suatu transaksi di suatu perusahaan harus berdasarkan otorisasi dari pejabat yang memiliki wewenang untuk menyetujui terjadinya transaksi tersebut.

Berikut adalah bagan alir (flowchart) sistem sistem pengendalian intern atas persediaan barang dagang $\mathrm{CV}$. A.M Banjarmasin yang seharusnya
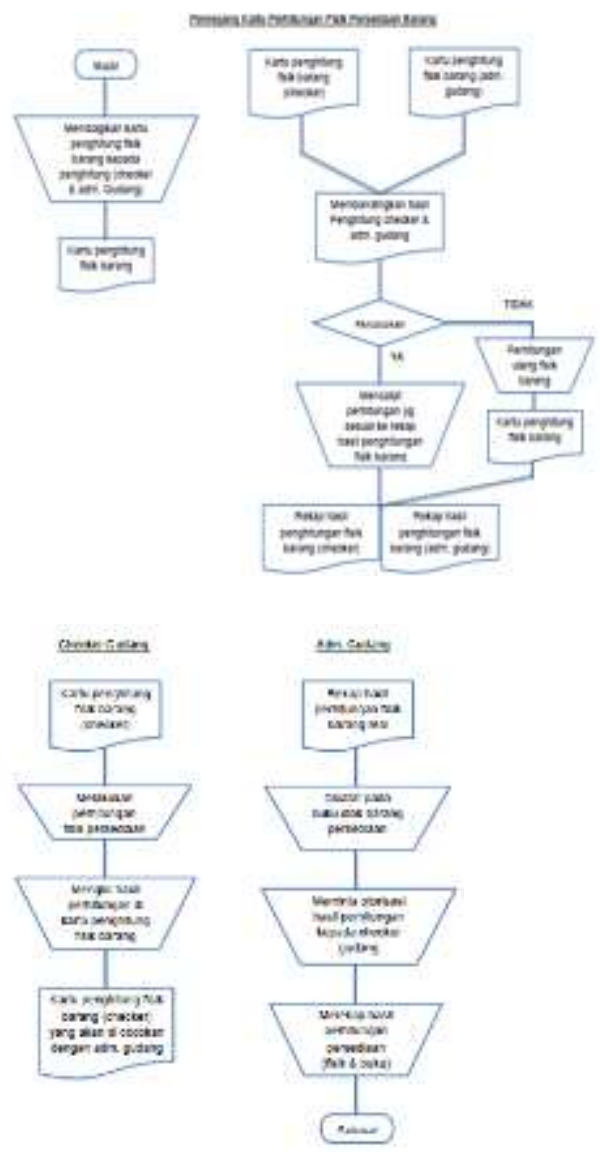

Gambar : 4.4 Flowchart Prosedur Persediaan Barang

Berdasarkan bagan alir (flowchart) tersebut dapat dijelaskan sebagai berikut :

a) Bagian checker gudang dan admin gudang harus memiliki atau mendapatkan kartu perhitungan fisik persediaan barang dagang, agar dapat menghitung atau menggolongkan jumlah fisik sesuai dengan item yang telah tersedia.

b) Setelah proses perhitungan fisik persediaan barang dagang yang telah dilaksanakan oleh bagian checker gudang dan admin gudang, harus membandingkan perhitungan yang telah dilaksanakan.

c) Pada saat proses pencocokan, ada 2 hal kemungkinan yang akan terjadi, yaitu : 
1) Jika hasil tidak sama, maka perhitungan fisik persediaan barang dagang di ulang kembali menggunakan kartu perhitungan fisik persediaan barang dagang yang baru

2) Jika hasil perhitungan fisik tersebut sama, maka hasil perhitungan fisik fisik barang tersebut dicatat ke rekap hasil perhitungan fisik barang

d) Setelah hasil perhitungan fisik persediaan barang dagang di rekap, maka rekap tersebut juga harus di simpan oleh bagian checker gudang dan admin gudang sebagai arsip gudang.

e) Selesai rekap hasil perhitungan fisik persediaan barang dagang, admin gudang mencatat ulang hasil perhitungan tersebut pada buku stok barang persediaan barang sesuai dengan item per masing-masing buku.

f) Kemudian admin gudang wajib meminta otorisasi hasil perhitungan kepada checker gudang guna menandakan bahwa segala pencatatan dan perhitungan fisik barang ada tanda mengetahui oleh checker gudang.

g) Apabila proses pencatatan dan perhitungan fisik persediaan barang dagang sudah selesai akan di rekap di kertas laporan stok gudang harian untuk dilaporkan kepada atasan dan divisi yang berkepentingan.

Dokumen yang disarankan untuk trasaksi perhitungan fisik persediaan barang dagang yang telah dijelaskan adalah barupa :

a) Kartu pershitungan fisik persediaan barang dagang

b) Rekap hasil perhitungan fisik barang persediaan barang dagang 2 rangkap (rangkap pertama untuk checker gudang dan rangkap kedua untuk admin gudang)

c) Buku pencatatan stok barang gudang per item.

d) Rekap hasil perhitungan persediaan (fisik \& buku) untuk laporan stok gudang harian

3) Praktik yang sehat dalam melaksanakan tugas dan fungsi setiap unit organisasi.

Tidak akan berjalan dengan baik jika tidak diciptakan praktik yang sehat dalam pelaksanaan kegiatan di sebuah perusahaan. Praktik yang sehat yang seharusnya dijalankan dalam pelaksanaan kegiatan sistem pengendalian intern persediaan barang dagang adalah sebagai berikut :

a)Penggunaan formulir bernomor urut tercetak yang penggunaannya harus dipertanggungjawabkan oleh yang berwenang belum dilaksanakan dengan baik oleh CV. A.M Banjarmasin. Maka sangat disarankan perusahaan tersebut menggunakan formulir bernomor urut tercetak sehingga penggunaannya dapat dipertanggung jawabkan oleh bagian yang berwenang.

b) Harus melakukan pemeriksaan mendadak tanpa pemberitahuan terlebih dahulu kepada bagian yang akan diperiksa dengan jadwal yang teratur.

c) Transaksi persediaan barang dagang sangat tidak diperbolehkan dari awal sampai akhir dilakukan oleh satu orang atau unit organisasi. Dan seharusnya CV. A.M pada transaksi retur barang dari penjualan sales kanvas, admin gudang harus ada ikut dalam mengawasi proses retur dan 
mencatat langsung barang dagang yang di proses.

d) Dilakukan perputaran jabatan agar dapat menjaga independensi pejabat dalam melaksanakan tugasnya. Sehingga kecil kemungkinan terjadinya kecurangan yang dilakukan oleh oknum pejabat itu sendiri.

e) Keharusan pengambilan cuti bagi karyawan yang berhak.

f) Melakukan pencocokan fisik kekayaan seperti persediaan barang dagang dengan pencatatan secara periodik.

g) Harus memiliki atau membentuk unit organisasi yang bertugas untuk mengecek efektivitas unsur-unsur pengendalian intern yang lain.

h) Tidak semua karyawan yang mutunya sesuai dengan tanggung jawabnya.

Karyawan yang mempunyai integritas yang tinggi sangat mendukung keefektifan sistem pengendalian intern barang dagang yang telah dijalankan. Adanya porsedur dan kebijakan yang telah ditetapkan oleh CV. A.M agar memperoleh karyawan yang mempunyai integritas yang tinggi dan sesuai dengan yang diharapkan akan leih baik juga dilakukan halhal sebagai berikut :

1. Mengadakan seleksi yang sesuai dengan tingkat pendidikan yang dibutuhkan dan berpengalaman di bidangnya.

2. Dilakukan tes sebelum karyawa diterima kerja.

3. Diadakan pelatihan program secara berjenjang bagi karyawan.

4. Melakukan kerja sama yang baik dan jelas dengan karyawan. Apabila karyawan belum bisa beradaptasi atau memenuhi kriteria sesuai dengan bidang yang dikerjakan, cukup melakukan kontrak kerja secara berkala misalnya 3 bulan sekali sampai karyawan tersebut memenuhi kriteria atau akan dipindahkan ke fungsi operasi yang lain.

Dari hasil perbandingan dengan penelitian terdahulu dalam penerapan system informasi akuntansi persediaan barang dagang bahwa system informasi akuntansi yang dapat memberikan informasi nya adalah didukung dengan program atau aplikasi yang sesuai dengan aktivitas perusahaan.

\section{Kesimpulan}

Berdasarkan hasil penelitian dan analisis yang telah dilaksanakan dalam skripsi ini, maka penulis dapat menyimpulkan bahwa :

1. Sistem Informasi Akuntansi Persediaan Barang Dagang yang berjalan :

a. Komponen sistem informasi akuntansi Persediaan Barang Dagang yang selama ini dilakukan belum optimal. Sistem aplikasi khusus yang dimiliki perusahaan tidak dipergunakan secara efektif sehingga sistem aplikasi tersebut hanya berfungsi untuk keperluan cetak nota atau faktur saja. Padahal sistem aplikasi tersebut dapat dipergunakan untuk pelaporan persediaan barang dagang yang diharapkan dapat membantu tim gudang agar prosedur operasional persediaan barang dagang dapat dikelola dengan baik. Sehingga sampai saat ini masih sering terjadi ketidakcocokan antara perhitungan fisik dengan perhitungan yang ada pada dokumen dan menimbulkan selisih.

b. Unsur-unsur sistem pengendalian intern yang selama ini dilakukan masih banyak yang perlu diperbaiki. Masih ada beberapa kelemahan pada saat pelaksanaan tugas pokok 
dan fungsi antar bagian banyak proses pekerjaan yang tidak ada dokumen rekamannya dan masih belum dapat memisahkan tanggung jawab fungsional secara tegas sehingga terjadi perangkapan tugas. Hal yang demikian akan memudahkan kemungkinan terjadinya penyimpangan atau kecurangan terutama kesalahan pencatatan persediaan barang dagang di gudang.

2. Sistem Informasi Akuntansi Persediaan Barang Dagang yang seharusnya:

a. Komponen sistem informasi akuntansi yang seharusnya dilakukan adalah perlunya pendukung kinerja aplikasi yang baik dan pengembangan kinerja dari aplikasi yang sudah ada, agar antara satu prosedur dengan prosedur yang lainnya dapat terjalin kerjasama yang baik. Serta data-data yang di proses harus menghasilkan data serta informasi yang akurat dan dapat dipertanggungjawabkan karena kualitas informasi yang dihasilkan sangat tergantung kepada kualitas data yang disajikan.

b. Unsur-unsur sistem pengendalian intern yang seharusnya dilakukan adalah sangat diperlukan adanya internal kontrol yang kuat, mulai dari proses pembelian barang dagang, penerimaan barang ke dalam gudang, dan pengeluaran barang dari gudang, serta sistem pencatatan yang akurat untuk memperbaiki sistem informasi persediaan yang diterapkan tersebut.

\section{Saran}

Berdasarkan hasil kesimpulan diatas untuk mengatasi permasalahan yang dihadapi dan menciptakan sistem informasi akuntansi dan sistem pengendalian intern persediaan barang dagang dengan baik, maka dapat diberikan saran sebagai berikut
1. Pelaksanaan sistem informasi akuntansi persediaan barang dagang yang seharusnya pada CV. A.M Banjarmasin hendaknya diterapkan sesuai dengan prosedur yang umum dan setiap periode tertentu harus dilakukan pengecekan atau pemeriksaan yang terbaru sesuai dengan aktivitas yang terjadi, serta diperlukannya aplikasi yang update dan dapat digunakan untuk semua divisi pada perusahaan. Juga diperlukan media atau komputer khusus untuk laporan stok setiap periodenya agar tidak terganggu oleh aktivitas kerja lainnya sehingga sistem informasi akuntansi yang dihasilkan dapat dipertanggungjawabkan khususnya untuk persediaan barang dagang.

2. Seharusnya sistem pengendalian intern persediaan barang dagang yang diterapkan harus memisahkan tanggung jawab fungsional secara tegas dalam pelaksanaan prosedur persediaan barang dagang agar tidak adanya perangkapan kerja.

\section{DAFTAR PUSTAKA}

Anastasia Diana dan Lilis Setiawati, Akuntansi Keuangan Menengah, (Yogyakarta: AndiOffset, 2017), 179.

IAI, Standar Akuntansi Keuangan Persediaan, (Garha Akuntan: Jakarta, 2018) hal 14.1.

Krismiaji, 2015, Sistem Informasi Akuntansi, Edisi keempat, Sekolah Tinggi Ilmu YKPN,Yogyakarta.

Mulyadi , 2016. Sistem Akuntansi. Jakarta: Salemba Empat.

Sujarweni, Wiratna. 2015. Sistem

Akuntansi. Yogyakarta: Pustaka

Baru Press.

Aprisanti, Ida Mahesa, 2014, Sistem Informasi Akuntansi Persediaan Barang Dagang Menggunakan Metode FIFO Pada Swalayan Aneka Jaya Semarang, 
http://www.media.neliti.com

(diakses tanggal 20 April 2020)

Adi, Seno Prafitri, 2015, Perancangan

Sistem Informasi Persediaan

Barang Pada PT. Inter Delta Tbk

Semarang,

http://www.eprints.dinus.ac.id

(diakses tanggal 05 Mei 2020)

Rahmawati, 2017, Sistem Informasi

Inventory Stok Barang Pada CV.

Artha Palembang,

http://www.eprints.radenfatah.ac.id

(diakses tanggal 08 Mei 2020)

Zagladi, Arief Noviarakhman, Sutrisno,

Melania, dan Fredy Jayen, 2018,

Pedoman Penulisan Skripsi STIE

Pancasetia Banjarmasin, Penerbit

Pancasetia, Banjarmasin. 